\title{
The effect of flour from the rind of the yellow passion fruit on glycemic control of people with diabetes mellitus type 2: a randomized clinical trial
}

Márcio Flávio Moura de Araújo ${ }^{1 *} \mathbb{B}$, Vivian Saraiva Veras ${ }^{1}$, Roberto Wagner Júnior Freire de Freitas ${ }^{2}$, Maria do Livramento de Paula ${ }^{3}$, Thiago Moura de Araújo', Lilian Raquel Alexandre Uchôa', Maria Wendiane Gueiros Gaspar', Maria da Conceição do Santos Oliveira Cunha', Maria Aparecida Alves de Oliveira Serra ${ }^{4}$, Carolina Maria de Lima Carvalho ${ }^{1}$, Edmara Chaves Costa ${ }^{1}$ and Marta Maria Coelho Damasceno ${ }^{4}$

\section{Abstract}

Background: The single or combined use of herbal and dietary products with medications has shown benefits in the metabolic modulation of carbohydrates, in the restoring of the function of pancreatic beta cells, and in insulin resistance. To analyze the effect of the use of flour made from the rind of the yellow passion fruit on the glycemic control of people with diabetes mellitus type 2 .

Methods: An open, prospective, randomized clinical trial was undertaken with 54 participants over an eight-week period. The participants from the case group were advised to ingest $12 \mathrm{~g}$ of the flour, three times daily; before breakfast, lunch and dinner.

Results: After eight weeks of use of the flour made from the rind of the yellow passion fruit, we did not identify significant statistical differences in the values for capillary blood glucose $(p=0.562)$, fasting blood glucose $(p=0.268)$ or glycated hemoglobin ( $p=0.229)$ between the study groups. In the case group, we identified an increase (29.6\%-37\%) of the people with normal $\mathrm{HbA}_{c}$; however, this did not have statistical relevance $(p=0.274)$.

Discussion: Based in our findings, we believe it is important to extend the time of exposure to the intervention and increase the rigor in the monitoring of adherence in future studies on this topic. Only in this way will we be able to make confident inferences in relation to the use of flour made from the rind of theyellow passion fruit as a therapeutic tool for glycemic and/or metabolic control in persons with DM 2.

Conclusions: In the sample in question, the use of the flour made from the rind of the yellow passion fruit, over an eight-week period, did not improve the glycemic control of people with type 2 diabetes. Trial registration: U1111.1187.3616. Registered 6 September, retrospectively registered, in the Brazilian Clinical Trials Registry.

Keywords: Diabetes mellitus, Glycemic Index, Passiflora

\footnotetext{
* Correspondence: marciofma@yahoo.com.br

${ }^{1}$ Professor of University for International Integration Lusophony Afro Brazilian,

CE 060, Km 51, S/N, Acarape CEP: 62785000, Ceará, Brazil

Full list of author information is available at the end of the article
} 


\section{Background}

Throughout humanity's history, herbal products and dietary supplements have been used in the treatment of diabetes type 2 (DM 2). This is the result of folk culture in the promotion of human health, which has often been looked down on. However, with the increase of diabetes and the socioeconomic and health costs associated with this, there is growing scientific interest in this issue [1-4].

The main characteristic of DM 2 is hyperglycemic, due to defects of insulin secretion, its peripheral resistance or both situations [5]. In long term this hyperglycemic framework is toxic to human body, since it stimulates the development of micro and macrovascular injuries that many times irreversible [6]. Both types have their origin in the poor glycemic control and they are responsible for morbidity and mortality rates. Diabetes complications can be divided in acute (related to eventual hyperglycemia) and chronic (related to poor metabolic control disease) [7].

The single or combined use of herbal and dietary products with medications has shown benefits in the metabolic modulation of carbohydrates, in the restoring of the function of pancreatic beta cells, and in insulin resistance. Furthermore, antioxidant properties and reduction in cardiovascular risk have been ascertained [8-10].

In virtue of this, researchers worldwide emphasize the need for studies with new natural products which employ rigorous methodological designs - the aim thus being to assess their efficacy, safety and mechanism of action [11-13]. In Brazil, one of the current proposals from the Ministry of Health is to encourage studies on decision-making in health which involve the development, validation, efficacy and consequent incorporation of technologies in the Unified Health System (SUS) [14].

One good example of this tendency is the passion fruit. Its sedative properties have been known for some time, especially when the infusion or tincture of the leaves is used $[15,16]$. Recently, however, a new property has been described related to the fruit: the hypoglycemic activity of the flour produced from its rind [17-20].

Passion fruit peel is rich in soluble fibers, mainly pectin, beneficial to the human being $[16,21]$. This pectin is widely used as an ingredient for pharmaceutical preparations, such as antidiarrheal and detoxifiers. In addition, it can reduce glycemic and lipid levels by forming a gel that prevents the absorption of cholesterol and glucose from the diet $[22,23]$.

To our knowledge, through a vast bibliographic survey, there have been only three intervention studies published on this topic. None of these, however, were characterized as randomized clinical trials $[17,20]$.

Brazil is a major world producer of the yellow species of passion fruit (Passiflora edulis f. flavicarpa Deg). Although the passion fruit is an organic product whose biological value is cherished in the community, its rind is not generally used. Its use in the community could create an awareness of a natural therapeutic aid in confronting DM 2. Currently, the glycemic and metabolic control of people with DM 2 is one of the main challenges in primary health care in Brazil [24, 25].

For the World Health Organization (WHO), Brazil's herbal potential must be used in the prevention, control and treatment of health problems, especially in primary health care. In Brazil, the number of nurses who undertake studies with medicinal plants or natural products continues to remain low in relation to the country's potential. This fact is explained by some health professionals' lack of adhesion to multi-professional work and to knowledge of folk remedies. It is necessary for nurses to advance in studies which involve the prescribing of natural products, with the aim of legitimizing this professional practice as an interdisciplinary action of healthcare [26-28].

As a result, this study's objective was to analyze the effect of flour made from the rind of the yellow passion fruit on the glycemic control of people with DM 2 over an eight-week period.

\section{Method}

This is an open, prospective, randomized clinical trial, held between November 2015 and March 2016 in the city of Redenção, in the State of Ceará, Brazil.

The study population was made up of people with DM 2 who were registered and monitored in primary care in Redenção, Ceará, Brazil - numbering, at the time of the study, 9,507 people. As eligibility criteria, we established: to be a person who had had DM 2 for at least 60 days; to be aged between 18 - 65 years old, of either sex; not to have liver or kidney problems (according to data from the medical record) and not to be allergic to products derived from passion fruit. We excluded the following people from the study: people with DM 1, people who used insulin or psychotropic medications, tobacco or alcohol (all of which disrupt or control blood glucose levels), and people with mild or serious cognitive loss [29].

In the calculation of sample size, a model was used for comparing two groups by quantitative variables with pairing of the cases [30]. For this, we therefore adopted: $\mathrm{nP}$ - number of pairs; $\mathrm{Z} \alpha / 2$ - $\alpha$-error value, usually: 1.96 (5\%); $\mathrm{Z} \beta$ - $\beta$-error value, usually: 0.84 (20\%); Sd standard deviation of the difference between the pairs; $\bar{D}-$ mean of the difference between the pairs.

In the above-mentioned sample calculation, we used a previous study's mean values and values for standard deviation [17], totaling 27 pairs distributed between the intervention and control groups. As discontinuity criteria, we placed adherence inferior to $75 \%$ to this study's intervention. 
For the pairing of the pairs, we took it as a rule they should have values for glycated hemoglobin $\left(\mathrm{HbA} 1_{\mathrm{c}}\right)$ which werre as similar as possible. Following that, after the first collection of biochemical data, each member of the pairs was randomized into the intervention or control groups by means of a draw (Fig. 1).

Prior to the field research, the nurses underwent $12 \mathrm{~h}$ of training. The participants were interviewed regarding sociodemographic and clinical data. Following that, on a further occasion, we undertook the measuring of anthropometric and glycemic variables. These, characterized as our main outcome, were capillary blood glucose (CBG), fasting blood glucose (FBG) and glycated hemoglobin $\left(\mathrm{HbA} 1_{\mathrm{c}}\right)$.

The collection and analysis of the biochemical specimens was undertaken by a private laboratory contracted for this purpose. The protocol for blood sample collection and capillary blood glucose, as well as values found were analyzed in accordance with the Guidelines of the Brazilian Society of Diabetes [31].

We collected $10 \mathrm{ml}$ of blood, stored in two tubes of $5 \mathrm{ml}$ each, with the anticoagulant sodium fluoride (for glucose determination). After the collection, the samples were processed and centrifuged at 2,200 rotations per minute (RPM) for $20 \mathrm{~min}$ in a digital serology centrifuge, LS3 Plus CELM ${ }^{\ominus}$. Then, $1 \mathrm{ml}$ serum and plasma samples were separated for biochemical dose determinations. In the assessment of biochemical parameters, commercial Labtest Diagnóstica $\mathrm{S} / \mathrm{A}^{\circ}$ kits were used, with standardized techniques, following the manufacturer's recommendations.
We also considered, as secondary outcomes, the following variables: central adiposity index (CAI), body mass index (BMI) and waist-hip ratio (WHR). The data were collected by nurses who had received specific training, and complied with the requirements for collection and analysis made available in the literature [32, 33]. At the end of the eight-week period, the anthropometric and glycemic variables were taken again.

The participants in the intervention group were advised to ingest $12 \mathrm{~g}$ of the vegetable flour studied, before the three main meals (breakfast, lunch and dinner), every day, over the eight-week period. We obtained this value after reading previous papers about that subject and with the support of some professionals (food engineer, dietician and pharmacist). To this end, the members of the case group received sufficient polyurethane sachets, each containing $12 \mathrm{~g}$ of the product, according to analytical balance, for four weeks. They were advised to consume the product along with other foods or even in drinks.

Subsequently, we undertook home visits to deliver the remaining sachets (for the following four weeks). On these occasions, the sachets which had been distributed and taken were counted; those participants with a percentage of adherence inferior to $70 \%$ were excluded from the study (discontinuity criteria). While this was happening, the participants from the control group received the currently-used treatment from the health service involved in the study.

The yellow passion fruit peel flour was produced in the Food and Herbs laboratory. Its composition was of carbohydrates $(82.7 \%)$, proteins $(9.1 \%)$, ashes $(5.8 \%)$ and lipids (2.2\%). Each $100 \mathrm{~g}$ of yellow passion fruit flower

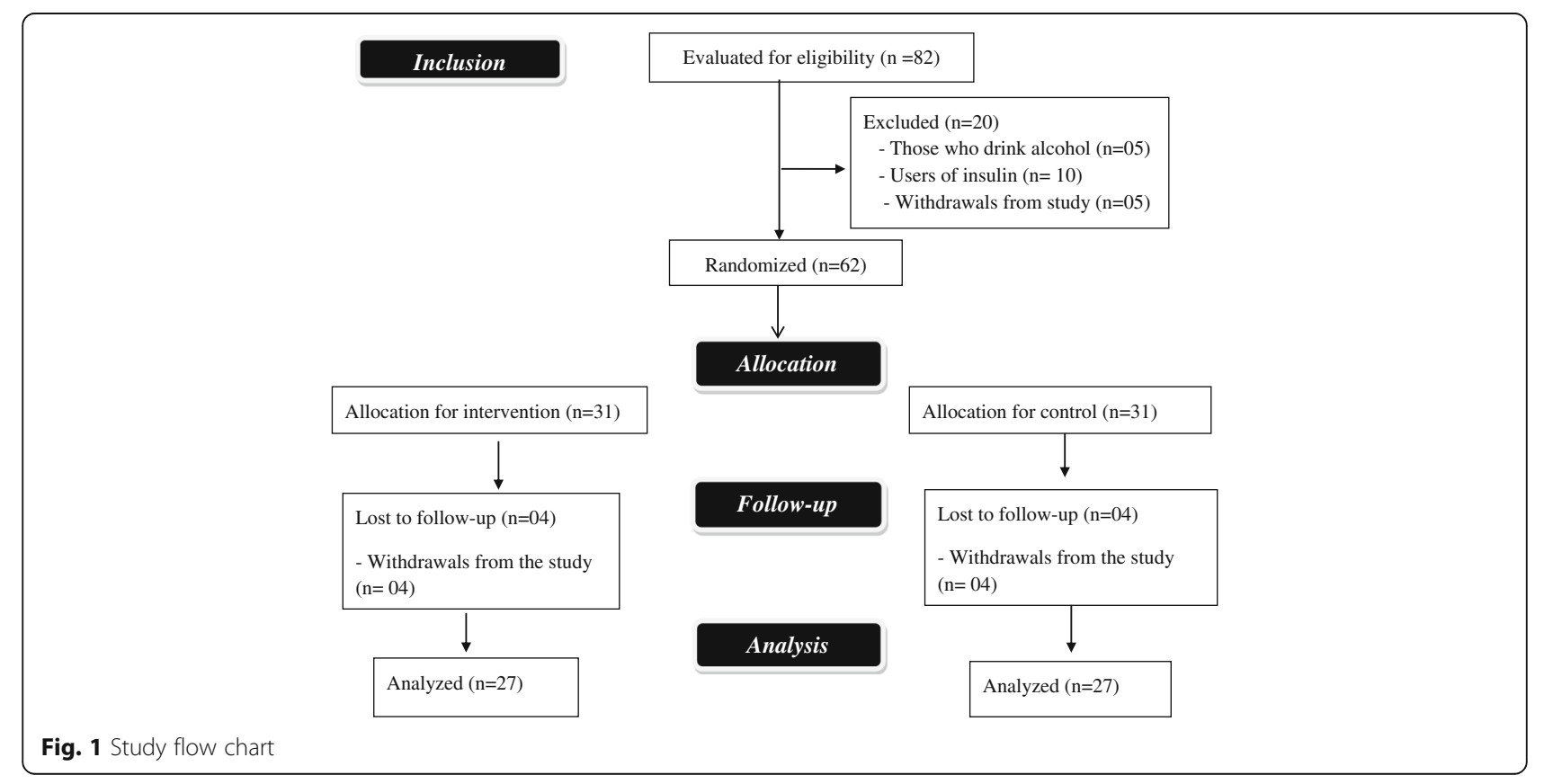


equaled approximately $388 \mathrm{Kcal}$ (kilocalories). It was subjected to micro and macroscopic analysis that guaranteed characteristic color, odor, taste and texture and absence of parasite, insect, rodent and general soil fragments. This analysis was guided by the quality inspection guideline of the Brazilian Association of Technical Standards (ABNT) n: 5426 [34].

We undertook comparison analysis between the groups through the use of the Student $t$-test for paired samples, in the continuous variables with normal distribution. Furthermore, we proceeded to intra-group comparison analysis, taking into account the mean values for the evaluations. In the case of asymmetric distributions, the Mann-Whitney test was used. The chi-squared test (or Fisher's exact test) was used for comparison of the categorical variables. We made ajustments in the statistical analysis data based on BMI and WHR (confouding variables) by ANCOVA test. The statistical analyses were undertaken using the Statistical Package for the Social Sciences (SPSS, Chicago) version 11 for Windows. We considered $p \leq 0.05$ in the calculations for inference of significant differences.

The study was approved by the Research Ethics Committee of the University for International Integration of the Afro-Brazilian Lusophony (Universidade da Integração Internacional da Lusofonia Afro Brasileira) in accordance with Opinion 828-534. This clinical trial was registered with the Brazilian Clinical Trials Registry (REBEC) under number U1111.1187.3616. All patients signed the informed consent form before their inclusion in the research.

\section{Results}

We can observe that the groups were, essentially, comprised of women (intervention group 81.4\% and 70.3\% in the control group) who were married, retired, and who lived with family members, as shown in Table 1.

In relation to age, we can also emphasize a predominance of young-elderly in both groups: the intervention group (64.1 \pm 10.9 years old) and control group (65.8 \pm 10.3 years old). Sedentarism was another specific characteristic in the groups analyzed: intervention (53.3\%) and control (46.6\%).

We observed that the participants of the control group presented a higher monthly income (US\$306.4 \pm 115.5 ) in relation to the intervention group (US\$253.2 \pm 74.4 ) $(p=0.049)$. A substantial proportion of the subjects, from both groups, were in the social class with lower purchasing power in Brazil (D and E -74\%), out of the six possible classes.

All the study participants used some form of medication for chronic health conditions. In both groups, we identified that little over half were using one or two oral antidiabetic drugs: intervention (55.5\%) and control (59.2\%).
From the baseline analysis, we can infer that the intervention and control groups were homogenous in relation to the outcomes of glycemic control, used in this study, as shown in Table 3.

Besides this, we did not identify significant statistical difference between groups in relation to variables BMI $(p=0.788)$, CAI $(p=0.233)$ and WHR $(p=0.345)$.

After the eight weeks of use of flour made from the rind of the yellow passion fruit, we did not identify significant statistical differences in the values for CBG $(p=0.562)$, FBG $(p=0.268)$ and $\mathrm{HbA}_{\mathrm{c}}(p=0.229)$ between the groups studied (Table 2). In the intervention group, we identified an increase $(29.6 \%-37 \%)$ of people with normal $\mathrm{HbA} 1_{\mathrm{c}}$; however, this did not have statistically significant relevance $(p=0.274)$.

Within each group, in the means for the variables of CBG, FBG and $\mathrm{HbA} 1_{c}$, we did not observe statistically significant differences. In the intervention group, we ascertained a slight reduction in the percentage of $\mathrm{HbA}_{\mathrm{c}}$, but this was not statistically significant over the study period $(p=0.608)$ as shown in Table 3.

Also in the intervention group, we did not observe statistically significant reductions in relation to the raw

Table 1 Distribution of the participants, by sociodemographic characteristics. Redenção, Brazil, 2016

\begin{tabular}{|c|c|c|c|}
\hline \multirow[t]{2}{*}{ Variables } & \multicolumn{2}{|l|}{ GROUP } & \multirow{2}{*}{$\begin{array}{l}p \\
\text { value }\end{array}$} \\
\hline & Case & Control & \\
\hline Sex & $\mathrm{N} \%$ & $\mathrm{~N} \%$ & \\
\hline Male & 0516.6 & 0829.6 & $0.339^{*}$ \\
\hline Female & 2281.4 & 1970.3 & \\
\hline \multicolumn{4}{|l|}{ Skin color } \\
\hline White & 0829.6 & 0622.2 & $0.296^{*}$ \\
\hline Black & 027.4 & 0622.2 & \\
\hline Mixed black/white & 1763 & 15100 & \\
\hline \multicolumn{4}{|l|}{ Occupation } \\
\hline Retired & 2074.0 & 2181.5 & $0.337^{*}$ \\
\hline Formal employment & 027.4 & 013.7 & \\
\hline Informal employment & 0414.8 & 013.7 & \\
\hline Housewife & 013.7 & 031.1 & \\
\hline \multicolumn{4}{|l|}{ Conjugal Situation } \\
\hline Married & 1140.7 & 1451.8 & $0.864^{*}$ \\
\hline Single & 0518.5 & 0415.8 & \\
\hline Widowed & 0829.6 & 0726 & \\
\hline Separated & 0311.1 & 027.4 & \\
\hline \multicolumn{4}{|l|}{ Lives with - } \\
\hline Family & 2281.5 & 1866.6 & $0.449^{*}$ \\
\hline Partner & 0311.1 & 0622.2 & \\
\hline Alone & 027.4 & 0311.1 & \\
\hline
\end{tabular}

Key: *Chi-squared test 
Table 2 Glycemic control of the intra-group participants after the eight week intervention. Redenção, Brazil, 2016

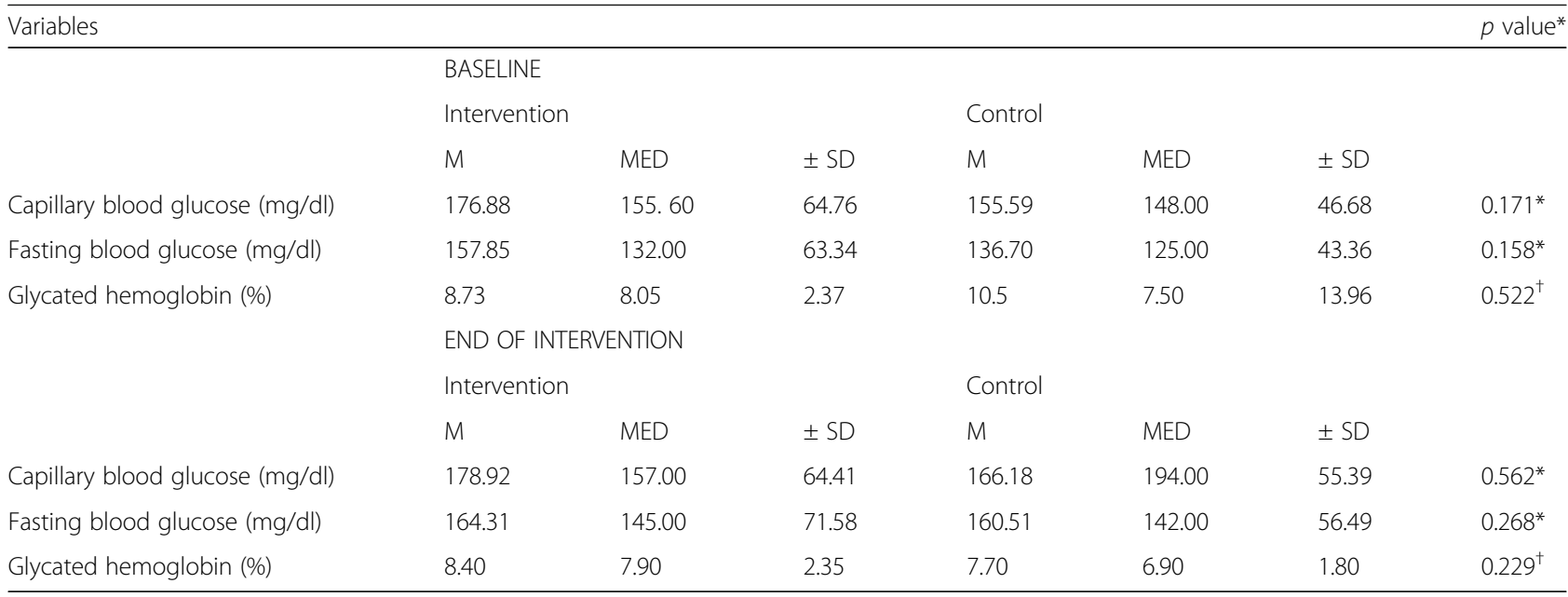

*Key: M-Mean; MED-Median; \pm SD- Standard Deviation; ${ }^{\dagger}$ Student $t$-test; *Mann-Whitney test

scores for the variables of CAI ( $p=0.717)$, BMI $(p=0.958)$ and WHR $(p=0.979)$ in the study period.

We observed the effects among variables CBG, FBG and $\mathrm{HbA} 1_{\mathrm{c}}$ by ANCOVA test. It's true that after adjusting to BMI and WHR the absence of significant statistical difference remained regarding the outcomes variables $\left(\mathrm{CBG}=0.440, \mathrm{FBG}=0.745\right.$ and $\left.\mathrm{HbA} 1_{\mathrm{c}}=0.218\right)$.

\section{Discussion}

The flour made from the rind of the yellow passion fruit (Passiflora edulis) is rich in pectin, a fraction of soluble fiber that has the capacity to retain water, forming viscous gels which delay gastric emptying and intestinal transit [35]. Another peculiarity of the use of this natural product is its inverse relationship with insulin resistance [36]. However, in the sample studied, its use was not efficacious in improving the glycemic control of people with DM 2 over an eight-week period. Due to some limitations of this study, it is necessary to be cautious in judging this finding.

We do not have a way of being certain that adherence to the use of the flour made from the rind of the yellow passion fruit was high $(270 \%)$ until the end of the intervention. Given that the monitoring of the taking of the flour in person only took place during the second home visit, the rest of the contact until the final assessment was by telephone. Moreover, people with mild cognitive deficits participated in the study - and may have had some difficulty in ingesting the product.

The three previous intervention studies found in the literature observed an improvement in the glycemia, even with periods of exposure and populations which were similar, and with a lower dose of the flour (10 g, $30 \mathrm{~g}$ and $30 \mathrm{~g}$, respectively). However, among these studies, only one adopted $\mathrm{HbA} 1_{\mathrm{C}}$ as an outcome, and

Table 3 Glycemic control of the intra-group participants after the eight-week intervention. Redenção, Brazil, 2016

\begin{tabular}{|c|c|c|c|c|c|c|c|}
\hline \multicolumn{7}{|l|}{ Variables } & \multirow[t]{2}{*}{$p$ value } \\
\hline & \multicolumn{6}{|c|}{ INTERVENTION } & \\
\hline & \multicolumn{3}{|l|}{ Before } & \multicolumn{3}{|l|}{ After } & \\
\hline & M & MED & $\pm S D$ & M & MED & $\pm S D$ & \\
\hline Capillary blood glucose (mg/dl) & 176.88 & 156.00 & 64.76 & 178.92 & 157.00 & 62.41 & $0.906^{*}$ \\
\hline Fasting blood glucose (mg/dl) & 157.85 & 132.00 & 63.34 & 164.31 & 145.00 & 71.54 & $0.726^{*}$ \\
\hline \multirow[t]{4}{*}{ Glycated hemoglobin (\%) } & 8.73 & 8.05 & 2.37 & 8.40 & 7.90 & 2.35 & $0.608^{\dagger}$ \\
\hline & \multicolumn{6}{|c|}{ CONTROL } & \\
\hline & \multicolumn{3}{|l|}{ Before } & \multicolumn{3}{|l|}{ After } & \\
\hline & M & MED & $\pm S D$ & M & MED & $\pm S D$ & \\
\hline Capillary blood glucose (mg/dl) & 155.59 & 148.00 & 46.68 & 166.18 & 153.00 & 55.39 & $0.451^{*}$ \\
\hline Fasting blood glucose (mg/dl) & 136.70 & 125.00 & 43.36 & 160.51 & 142.00 & 56.49 & $0.088^{*}$ \\
\hline Glycated hemoglobin (\%) & 10.50 & 7.50 & 13.39 & 7.70 & 6.90 & 1.80 & $0.307^{\dagger}$ \\
\hline
\end{tabular}

*Key: M-Mean; MED-Median; \pm SD- Standard Deviation; ${ }^{\dagger}$ Student $t$-test; *Mann-Whitney test 
all were based in self-controlled samples (studies of the 'before and after' type) $[17,18,20]$.

The absence of randomization may have caused overestimation of the effect of the intervention studied in the above-mentioned publications. Furthermore, a significant proportion of the statistical techniques in the three previous studies have premises which are only achievable through the use of randomization techniques [37].

For the main specialized scientific societies, $H b A 1_{C}$ is the gold standard in assessing glycemic control. As this reflects previous glycemic control (meaning glycemia over the last 120 days) it is possible that the second measurement may reflect the prior period [38]. Even so, we ascertained reduction in this parameter (not significant) in only eight weeks in this sample.

The importance of including foods or plants which promote an improvement in glucose tolerance, in the diets of people with DM, has been studied in primary health care in Brazil [39-42]. This fact can be explained by the richness of Brazil's natural heritage and by the need to seek tools of care in the cultures of the different regions of Brazil? (Brazil's National Health Promotion Policy). In spite of this, outside Brazil, there continues to be a great need to list new evidence and/or information in order to definitively officialize the use of natural products in the traditional clinical care of the person with DM [11, 12, 43].

It is incorrect to think that all natural and/or phytotherapy products are totally efficacious and/or safe in the control of DM [1]. Indeed, the American Diabetes Association (ADA) and/or the SBD do not have any specific guidelines regarding the management of these alternative products or therapies. There is also an absence of robust evidence demonstrating the efficacy of dietary supplements in the management of diabetes. This is principally the result of the lack of standardization of these formulas, and of the studies' small samples and methodological flaws $[1,44]$. The ADA accepts these products' use so long as they are recommended and/or used under the supervision of a health professional who must assess the safety and efficacy of these products prior to indicating them to the patients [44-46].

Based in our findings, we believe it is important to extend the time of exposure to the intervention and increase the rigor in the monitoring of adherence in future studies on this topic. Only in this way will we be able to make confident inferences in relation to the use of flour made from the rind of the yellow passion fruit as a therapeutic tool for glycemic and/or metabolic control in persons with DM 2. In addition, it is important to extend the study of the effects of this vegetable product among people with other chronic health conditions, such as metabolic syndrome, obesity and hypertension.

\section{Conclusion}

In the sample in question, the use of flour made from the rind of the yellow passion fruit, over an eight-week period, did not improve glycemic control of people with type 2 diabetes.

\section{Abbreviations \\ ABNT: Brazilian Association of Technical Standards; ADA: American Diabetes Association; BMl: Body mass index; CAl: Central adiposity index; CBG: Capillary blood glucose; DM 2: Diabetes type 2; FBG: Fasting blood glucose; HbA1c: Glycated hemoglobin; REBEC: Brazilian Clinical Trials Registry; SBD: Brazilian Society of Diabetes; SPSS: Statistical Package for the Social Sciences; SUS: Unified Health System; WHO: World Health Organization; WHR: Waist-hip ratio}

\section{Acknowledgements \\ Not applicable.}

\section{Funding}

The research received financial support of the Consel of Technological and Scientific Development from Brazil.

Availability of data and materials

The datasets used and/or analysed during the current study available from the corresponding author on reasonable request.

\section{Authors contributions}

Conception: MFMA; VSV; RWJFF; MLP; MMCD. Design: MFMA; VSV; RWJFF; MLP. Data Acquisition: MFMA; VSV; MLP; TMA; LRAU; MWGG; MCSOC, Data Analysis: MFMA; MLP; TMA; ECC; LRAU; MCSOC; CMLC; MAAOS, Drafted Manuscript: MFMA; RWJFF; MLP; ECC; LRAU; CMLC; MMCD; MAAOS, Gave Final Approval: MFMA; RWJFF; ECC; MWGG; MCSOC; MAAOS, Agrees to be held accountable for all aspects of work, ensuring integrity and accuracy: MFMA; VSV; MLP; RWJFF; ECC; CMLC. All authors read and approved the final manuscript.

Authors' information

Not applicable.

Competing interests

The authors declare that they have no competing interests.

Consent for publication

All participants gave informed consent for the research and publication data, and that their anonymity was preserved.

\section{Ethics approval and consent to participate}

The research conforms to the provisions of the Declaration of Helsinki in 1995 (as revised in Edinburgh 2000). The protocol for the research project has been approved by Ethics Committee for Research Involving Human Beings at University for International Integration of the Lusophony Afro Brazilian under protocol number $n^{\circ} 828537$

\section{Publisher's Note}

Springer Nature remains neutral with regard to jurisdictional claims in published maps and institutional affiliations.

\section{Author details}

${ }^{1}$ Professor of University for International Integration Lusophony Afro Brazilian, CE 060, Km 51, S/N, Acarape CEP: 62785000, Ceará, Brazil. Researcher from Oswaldo Cruz Foundation, Eusébio, Brazil. ${ }^{3}$ Food Engineer, PhD in Food Sciences, Federal University of Maranhão, São Luís, Brazil. ${ }^{4}$ Professor Federal University of Ceara, Fortaleza, Brazil. 


\section{Received: 23 December 2016 Accepted: 5 April 2017}

\section{Published online: 17 April 2017}

\section{References}

1. Zareba G, Serradell N, Castaner R, Davies SL, Prous J, Mealy N. Phytotherapies for diabetes. Drugs Future. 2005;30(12):1253.

2. Bell RA, Suerken CK, Grzywacz JG, Lang W, Quandt SA, Arcury TA. Complementary and alternative medicine use among adults with diabetes in the United States. Altern Ther Health Med. 2006;12:16-22.

3. Shaen-Whorter ML. Botanical dietary supplements and the treatment of diabetes: what is the evidence? Curr Diab Rep. 2005;5:391-8.

4. Herman PM, Poindexter BL, Witt CM, Eisenberg DM. Are complementary therapies and integrative care cost-effective? A systematic review of economic evaluations. BMJ Open. 2012;2:1-17.

5. Sociedade Brasileira de Diabetes. Diretrizes da Sociedade Brasileira de Diabetes 2009. 3rd ed. Itapevi: SBD; 2009.

6. American Diabetes Association. Standards of medical care in Diabetes, 2013. Diabetes Care. 2013;36(Supl.1):S11-66.

7. Dom M, Calder A, Mat R. Características clínico epidemiológicas de las complicaciones agudas de la diabetes en el servicio de urgências del Hospital General de Atizapán. Rev Fac Med. 2013;56(2):25-36.

8. Franz MJ, Boucher JL, Evert AB. Evidence-based diabetes nutrition therapy recommendations are effective: the key is individualization. Diabetes Metab Syndr Obes. 2014;7:65-72. doi:10.2147/DMSO.S45140.

9. Pandey A, Tripathi P, Pandey R, Srivatava R, Goswami S. Alternative therapies useful in the management of diabetes: a systematic review. J Pharm Bioallied Sci. 2011;3(4):504-12. doi:10.4103/0975-7406.90103.

10. Birdee GS, Yeh G. Complementary and alternative medicine therapies for diabetes: a clinical review. Clin Diabet. 2010;28(4):147-55.

11. Tang HC, Chen CYC. In Silico design for adenosine monophosphate-activated protein kinase agonist from traditional Chinese medicine for treatment of metabolic syndromes. Evid Based Alternat Med. 2014; Article ID 928589, 16 dx.doi.org/10.1155/2014/928589.

12. Tackett $\mathrm{KL}$, Jones MC. Complementary and alternative medicines for the treatment of diabetes. J Pharm Pract. 2009:22:546.

13. Dham S, Shah V, Hirsch S, Banerj MA. The role of complementary and alternative medicine in diabetes. Curr Diab Rep. 2006;6:251-8.

14. Brasil. Ministério da Saúde. Regimento Interno da Comissão Nacional de Incorporação de Tecnologias no Sistema Único de Saúde. Portaria N².009, de 13 de setembro de 2012. 2012.

15. Oliveira LF, Nascimento MRF, Borges SV, Ribeiro PCN, Ruback VR. Aproveitamento alternativo da casca do maracujá amarelo (Passiflora edulis f. flavicarpa) para produção de doce em calda. Cienc Tecnol Aliment. 2002;22(3):259-62.

16. Guertzenstein SMJ. Caracterização da farinha da casca de maracujá (Passiflora edulis, f. flavicarpa, DEG) cv. amarelo como fonte de fibra solúvel para alimentação humana. Rio de Janeiro: Universidade Federal do Rio de Janeiro: 1998

17. Janebro DI, Queiroz MSR, Ramos AT, Sabaa-Srur AUO, Cunha MAL, Diniz MFFM. Efeito da farinha da casca do maracujá-amarelo (Passifl ora edulis $f$. flavicarpa Deg.) nos níveis glicêmicos e lipídicos de pacientes diabéticos tipo 2. Rev Bras Farmacognosia. 2008;18(Supl.1):724-32.

18. Medeiros JS, Diniz MFM, Sabaa AUO. Avaliação das atividades hipoglicemiantes e hipolipemiantes da casca do maracujá amarelo (Passiflora edulis, f. flavicarpa). Rev. Bras. Anal. Rev Bras Anal Clin. 2009;41(2):99-101.

19. Barbalho SM, Damasceno D, Spada APM, Lima IERN, Araújo AC, Guiquer EL, et al. Effects of passiflora edulis on the metabolic profile of diabetic wistar rat offspring. J Med Food. 2011;14(12):1490-95.

20. Queiroz MSR, Janebro DI, Cunha MAL, Medeiros JS. AUO Sabaa-Srur, Diniz MFFM, et al. Effect of the yellow passion fruit peel flour (Passiflora edulis $\mathrm{f}$. flavicarpa deg.) in insulin sensitivity in type 2 diabetes mellitus patients. Nutri J. 2012;11(89):1-7.

21. Yapo BD, Koff KLK. Yellow passion fruit rind a potential source of low-methoxyl pectin. J Agric Food Chem. 2006;54:2738-44.

22. Fietz VR, Salgado JM. Efeito da pectina e da celulose nos níveis séricos de colesterol e triglicerídeos em ratos hiperlipidêmicos. Ciênc Tecnol Aliment. 1999;19(3):318-21.

23. D’Addosio R, Páez G, Marín M, Mármol Z, Ferrer J. Obtención y caracterización de pectina a partir de la cáscara de parchita (Passiflora edulis $f$. flavicarpa Degener). Rev Fac Agron. 2005;22(3):241-51.
24. Veras VS, Araújo MFM, Rodrigues FFL, Santos MA, Damasceno MMC, Zanetti ML. Assessment of metabolic control among patients in a capillary glucose self-monitoring program. Acta Paul Enferm. 2012;25(3):453-8.

25. Araújo MFM, Freitas RWJF, Fragoso LVC, Araújo TMA, Damasceno MMC, Zanetti ML. Cumprimento da terapia com antidiabéticos orais em usuários da atenção primária. Texto Contexto Enferm. 2011;20(1):135-43.

26. Borges AM, Ceolim T, Barbieri RL, Heck RM. A inserção das plantas medicinais enquanto prática da enfermagem: um crescente desafio. Rev Enfermería Global. 2010:18:1-8.

27. Alvim NAT, Ferreira MA, Cabral IE, Almeida Filho AJ. O uso de plantas medicinais como recurso terapêutico: das influências da formação profissional às implicações éticas e legais de sua aplicabilidade como extensão da prática de cuidar realizada pela enfermeira. Rev Latino-Am Enfermagem. 2006;14(3):316-23.

28. Brasil. Ministério da Saúde. Política Nacional de Plantas Medicinais e Fitoterápicos. Brasília: Health Brazilian Ministery. 2006.

29. Folstein MF, Folstein SE, McHugh PR. "Mini-mental state". A practical method for grading the cognitive state of patients for the clinician". J. Psychiatry Res. 1975;12(3):189-98.

30. Miot HA. Tamanho da amostra em estudos clínicos e experimentais. J Vasc Bras. 2011;10(4):275-8.

31. Sociedade Brasileira de Diabetes. Diretrizes da Sociedade Brasileira de Diabetes. 2015-2016. Rio de Janeiro: AC Farmacêutica.

32. Bergman RN, Stefanovski D, Buchanan TA, Sumner AE, Reynolds JC, Sebring NG, et al. A better index of body adiposity. Obesity. 2011;19(5):1083-9.

33. Duarte ACG, Castellani FR. Semiologia Nutricional. 1st ed. Rio de Janeiro: Axcel; 2002

34. Associação Brasileira de Normas Técnicas. Planos de amostragem e procedimentos na inspeção por atributos -NBR5426. 1989.

35. Galisteo M, Duarte J, Zarzuelo A. Effects of dietary fibers on disturbances clustered in the metabolic syndrome. J Nutr Biochem. 2008;19:71-84.

36. Ylonen K, Saloranta C, Kronberg-kippila C, Groop L, Aro A, Virtanen SM. Associations of dietary fiber with glucose metabolism in non diabetic relatives of subjects with type 2 diabetes: the Botnia Dietary. Diabetes Care. 2003;26(7):1979-85.

37. Mexas F, Efron A, Chaisson RE, Conde MB. Understanding and retention of trial-related information among participants in a clinical trial after completing the informed consent process. Clin Trials. 2014;11:70-3.

38. American Diabetes Association (ADA). Standards of Medical Care in Diabetes. Diabetes Care. 2015;38(Suppl.1):S1-S2.

39. Ferreira EB, Fernandes LC, Galende SB, Cortez DAG, Bazotte RB. Hypoglycemic effect of the hydroalcoholic extract of leaves of Averrhoa carambola $\mathrm{L}$. (Oxalidaceae). Rev. Bras. Farmacogn. 2008;18:339-43.

40. Barbosa-Filho JM, Vasconcelos THC, Alencar AA, Batista LM, Oliveira RAG, Guedes DN, et al. Plants and their active constituents from South, Central, and North America with hypoglycemic activity. Rev Bras Farmacogn. 2005;15:392-413.

41. Silva MIG, Gondim APS, Nunes IFS, Sousa FCF. Utilização de fitoterápicos nas unidades básicas de atenção a saúde da família no município de Maracanaú (CE). Rev Bras Farmacogn. 2006;16:455-62.

42. Santos HB, Modesto-Filho J, Diniz MFFM, Vasconcelos THC, Pereira FSB, Ramalho JA, et al. Avaliação do efeito hipoglicemiante de Cissus sicyoides em estudos clinicos fase II. Rev Bras Farmacogn. 2008;18(1):70-6.

43. Mucalo I, Jovanovski E, Vuksan V, Bodikov V, Celjko R, Dario R. American ginseng extract (Panax quinquefolius L.) is safe in long-term use in type 2 diabetic patients. Evid. Based. Alternat Med. 2014: 969168.

44. Yeh GY, Eisenberg DM, Kaptchuk TJ, Phillips RS. Systematic review of herbs and dietary supplements for glycemic control in diabetes. Diabetes Care. 2003;26:1277-94.

45. American Diabetes Association. Patient information: guidelines for using vitamin, mineral, and herbal supplements. Diabetes Spectr. 2001;14:160.

46. American Diabetes Association. Unproven therapies (position statement). Diabetes Care. 2004:27 Suppl 1:S135. 